\title{
Paleopathological Findings in Cranial Series from a Necropolis of a Medieval Town of Drustar (Silistra), Bulgaria
}

\author{
Silviya Nikolova \\ National Anthropological Museum with Research group, \\ Institute of Experimental Morphology, Pathology and Anthropology with Museum, \\ Bulgarian Academy of Sciences, Sofia, Bulgaria E-mail: sil_nikolova@abv.bg \\ Diana Toneva \\ National Anthropological Museum with Research group, \\ Institute of Experimental Morphology, Pathology and Anthropology with Museum, \\ Bulgarian Academy of Sciences, Sofia, Bulgaria
}

\section{Doi:10.5901/mjss.2013.v4n11p640}

\section{Abstract}

The comprehensive study of the various paleopahological findings on bone material is of great importance for the biological reconstruction. It is also a valuable source of information about the way of life of the past populations. In this study we described some paleopathological findings on cranial series obtained from archaeological excavation of a necropolis of the medieval town of Drustar (9th-15th century), Northeastern Bulgaria. Drustar was the most important Bulgarian fortress of the lower Danube. This town was connected with the earlier history of Bulgaria since it was one of the first places in which the Slavic people and the Bulgars were settled after they passed over Danube. The town was also an inheritor of the Roman town Durostorum, called Dorostol from the Byzantines. From the Ottoman period in Bulgaria till today the town bears the name Silistra. The investigated cranial series includes a total of 196 crania (70 male, 50 female, 59 infant, and 17 unidentified). There are two cases of traumas inflicted as a probable result of battle injuries in adult male individuals. In a few individuals is observed cribra orbitalia as an evidence of anemia. Concerning the jaw and tooth pathology the most common findings were the dental caries with related complications. There are also some cases of alveolar atrophy in adult individuals and cases of temporomandibular joint arthritis as well.

\section{Introduction}

The comprehensive study of the varied findings discovered during archaeological excavations is a valuable source of information for the way of life of the past populations. Diseases have played an important role in the course of human history and in the development of human civilization. The consequence of different pathological processes and traumatical bone damages are an evidence for the spread and frequency of a number of diseases and also for the development of medicine.

The aim of this study is to describe some paleopathological findings on cranial series obtained from archaeological excavation of a necropolis of the medieval town of Drustar (9th $-15^{\text {th }}$ century), Northeastern Bulgaria. The investigated necropolis was situated around and within the basilica, which was near to the northern fortress wall. The basis of the basilica was revealed in 1993 year during excavations in the National archaeological reserve "Durostorum-DrustarSilistra", supervised by associate professor Stefka Angelova (Angelova, 2002). The necropolis was dated $9^{\text {th }}-15^{\text {th }}$ century as the burials from the 14th century were numerous.

Drustar was connected with the earlier history of Bulgaria. This town was the most important Bulgarian fortress of the lower Danube. Furthermore, this was one of the first places in which the Slavic people and the Bulgars were settled after they passed over Danube. Therefore, a study of bone material from this region is of great importance for the biological reconstruction.

\section{Material and methods}

The study was performed on a cranial series from medieval necropolis in Drustar. The investigated series included a total 
of 196 crania: 70 males, 50 females, 59 infants and 17 adult individuals with unidentified sex and age (Table 1).

Sex and age of the individuals was determined on the basis of the metrical and morphological features on the skulls and postranial skeletons.

Macroscopical observation on the bone material was used. The bone changes were detailed examined and documented.

Table. 1: Sex and age distribution of the buried individuals

\begin{tabular}{|l|c|c|c|c|c|}
\hline \multicolumn{1}{|c|}{ Age categories } & Total count by age & Male & Female & Infant & Individuals with unidentified sex and age \\
\hline Infans I (0-7) & 46 & 0 & 0 & 46 & 0 \\
\hline Infans II (7-14) & 13 & 0 & 0 & 13 & 0 \\
\hline Juvenilis (14-20) & 3 & 0 & 3 & 0 & 0 \\
\hline Adultus (20-40) & 78 & 45 & 33 & 0 & 0 \\
\hline Maturus (40-60) & 36 & 23 & 13 & 0 & 0 \\
\hline Senillis (over 60$)$ & 3 & 2 & 1 & 0 & 0 \\
\hline Total count by sex & 196 & 70 & 50 & 59 & 17 \\
\hline
\end{tabular}

\section{Results and discussion}

\subsection{Description of the paleopahtological findings}

\subsubsection{Trauma of the skull}

There are two cases of traumas inflicted as a probable result of battle injuries in adult male individuals. The first finding is a relatively small concavity with oval shape and blunted edges upon the left parietal bone on an adult male skull (Fig. 1). The damage involves the both outer and inner table. Depressed fractures often but not always affect the inner table and if these heal they tend to leave a circular depression in the cranial vault (Orthner, 2003). According to Aufderheide and Rodriguez-Martin (1998) low velocity injuries affect a broad area and generate linear fractures while the energy of high velocity impacts is often focused on smaller areas causing depressed fractures. Consequently the bone defect (depressed skull fracture) in this case is caused by a blow with blunt object with high velocity (slingshot injury?). The lesion was well healed indicating long survival after the injury i.e. the trauma was not lethal.

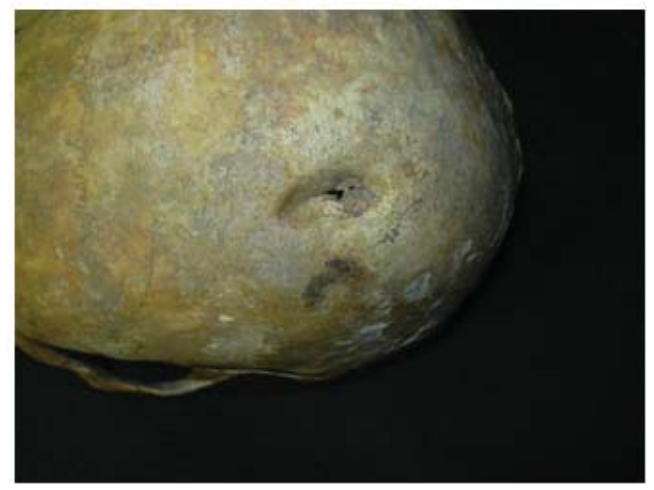

Fig. 1. Skull trauma caused by a blow with blunt object upon the left parietal bone on an adult male skull

The second finding is observed on a skull belonged to a mature male individual. The bone defect represents a groove upon the both parietal bones (Fig. 2a, 2b). It is situated near to the coronal suture and passing obliquely through the sagittal suture. This linear indentation of the outer table most probably represents a cut trauma with sharp object. The rounded edges suggested that the trauma was survived. Investigation of the postcranial skeleton of this individual revealed also a healed fracture of the right ulna. Most probably the two traumas were obtained simultaneously as a result of battle injuries. 


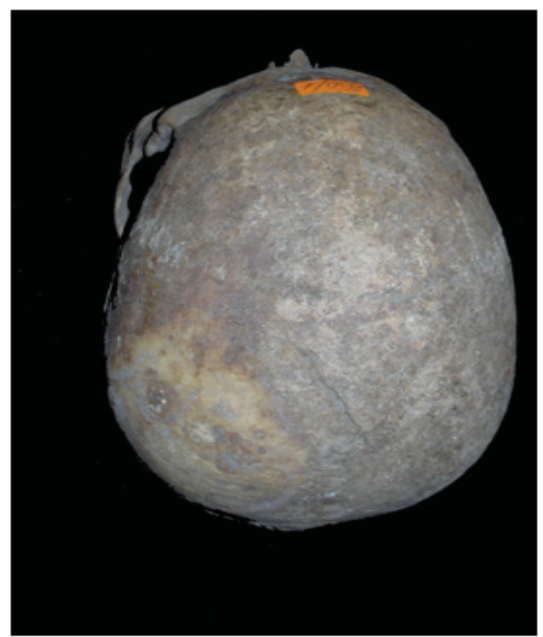

Fig. 2a. Skull trauma caused with a sharp object upon the both parietal bones on a mature male individual

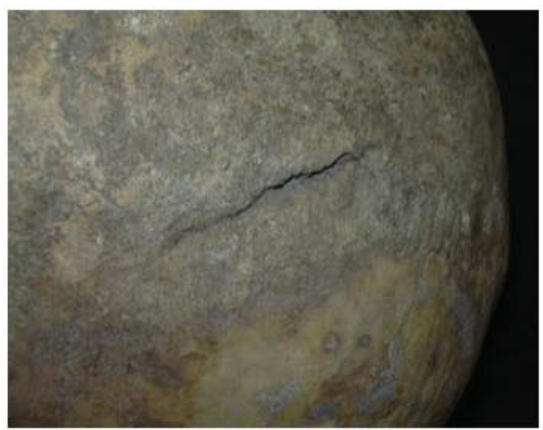

Fig. $2 \mathrm{~b}$. Bone defect represent a linear indentation of the outer table of the skull

Thus, most studies demonstrate a substantial predominance of skull fractures in males and location of the lesions on the left side of the cranium, implying that the pathology was acquired by a face-to-face encounter with a right handed opponent. By far the most common injury is a concave indentation of the outer table. (Aufderheide and Rodriguez-Martin, 1998).

Trauma to the skull, particularly injury sufficiently severe to cause fracture, results in a vascular response, including increased fluid. Within the enclosed cranium the increased pressure from the fluid can cause damage to the brain tissues and relieving the pressure buildup is an important component in treating skull trauma (Orthner, 2003). The two survived cases of head wounds are an indicator for the level of medical treatment for this period. Moreover, in both cases there are no evidences for complications arising from the factures such as infection, tissue necrosis and so on.

\subsubsection{Hematopoietic Diseases}

In 11 cases (8 infant, 2 females and 1 male) are observed lesions located bilaterally on the orbital roof (symmetrical orbital osteoporosis). In four of the infant individuals the involved areas are thickened by the expanded diploic layer and the outer table overlying the lesions is completely resorbed. This permits direct visualization of the trabeculae of the expanded cancellous bone (Fig. 3). 


\section{Fig. 3. Cribra orbitalia}

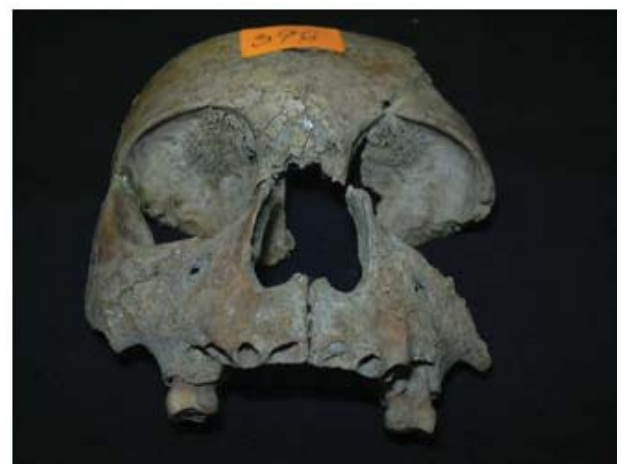

All these secondary bone changes are known as porotic hyperostosis $(\mathrm{PH})$ or cribra orbitalia (CO) and are most commonly linked to some kind of anemia. PH is a porous enlargement of the bone tissue. In some situations the external gross appearance may consist of labyrinth-like plates of bone. The porous nature of the abnormal bone varies from fine, pumice-like pores to large pores in excess of $2 \mathrm{~mm}$ in diameter. A single lesion may contain all variation of porosity (Orthner, 2003). Through the descriptive analysis of the gross lesions including cross-sectional appearance it is obviously that in our cases the most probable pathogenesis of these lesions is a stimulus from anemia to increase the space for hematopoietic marrow. This marrow hypertrophy causes an enlargement of diploe at the expense of the outer table. Moreover, in the aforementioned four infant cases, $\mathrm{CO}$ represents active lesions of anemia typical for young individuals. The inactive form of $\mathrm{CO}$ in older individuals, where the orbital roof has begun remodeling itself, represents a healing stage of a previously more overt lesion. Unfortunately the diagnosis of a specific type of anemia only on a skeletal morphological basis is difficult, because the skeletal changes are similar. Porotic hyperostosis caused by other diseases, such as infection or scurvy, tends to have important differences in cross-sectional morphology as the bone enlargement is the result of activation of the periosteum and the lesions are superficial to the outer table. In such a case there is no significant change in the diploic space or the outer table (Orthner, 2003).

\subsubsection{Dental Diseases and pathological conditions of jaws}

Concerning the jaw and tooth pathology the most common findings are the dental caries with related complications such as granulomatous lesions and cysts of the adjoining tissues of the affected teeth. There are also some cases of alveolar atrophy in adult individuals and cases of temporomandibular joint arthritis as well (Fig. 4).

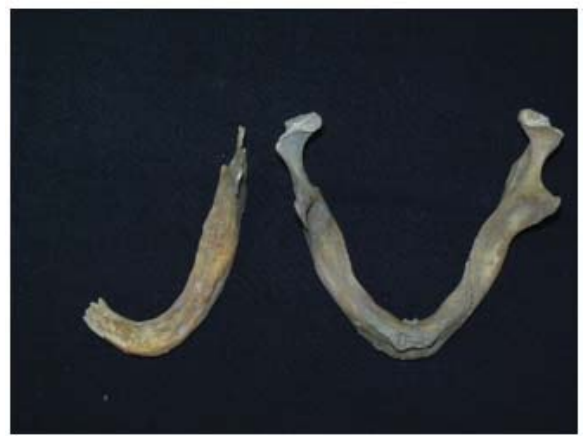

Fig. 4. Alveolar atrophy and temporomandibular joint arthritis

In a mandible belonged to a mature individual of unidentified sex, the genial tubercle of the right side is remarkably increased (Fig. 5). This mandible is also with alveolar atrophy and almost entirely edentulous. According to MacLeod and MacIntyre (1992) the resorption of the edentulous mandible can lead to the genial tubercles taking up a relatively 
superficial position. The authors presented case where resorption was accompanied by calcification of the insertion of genioglossus resulting in the development of a painful mass in the floor of the mouth. Selvamuthukumar et al. (2010) describer similar case with a spike like projection originating from the genial tubercular region. The authors diagnosed this case as an oral carcinoma and hypertrophy of genial tubercle.

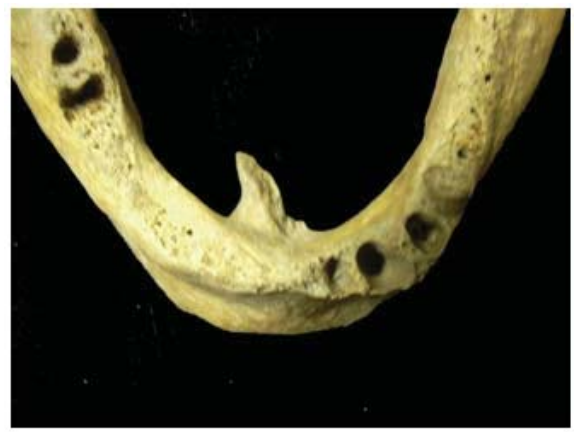

Fig. 5. Hypertrophy of right genial tubercle

\subsection{Discussion}

There are previous investigations of the paleopathological findings from different territories of Bulgaria. According to Kondova and Cholakov (1992) the high frequency of symmetric orbital osteoporosis in the late antique population of Augusta Trayana (Stara Zagora), great administrative centre in Romen province Thracia, indicates congenital haemolytic anemias of thalassemia type. Moreover half of the cases are in second and third stage of development - cribra orbitalia porotica and cribra orbitalia trabecularis. According to tooth-maxillary paleopathology, the caries damages and their complications of constant teeth appear in children yet, and gradually increase with age.

In vast studies of the medieval Bulgarian population paleopathology, based on an investigation of numerous necropolis, Boev et al. (1981) and Kondova et al.(1982) discussed some traumatic inflicts as a result of labour or war reasons. They also described two cases of trephining for curing purposes. In these investigations the authors described cribra orbitalia as a condition connected with different in origin anemias. In series from Tatul, Kardjali district $\left(12^{\text {th }}-14^{\text {th }}\right.$ century) they discover orbital osteoporosis in $9,1 \%$ of the skulls probably due to bad nourishing diet.

In 1993 Tcholakov investigated medieval necropolis from Drustur. The necropolis was revealed beside the southern fortress wall of the early Byzantium town Dorostol and was dated $12^{\text {th }}-14^{\text {th }}$ century. Most of the burials were from the $13^{\text {th }}$ century. The author found two depressed skull fractures caused by a blow with a blunt object and healed without complications. The first injury was on the frontal bone in mature male imdividual and the second - on the right parietal bone in adult male individual. In five cases (four infants and one adult female) the author found secondary bone changes - osteoporosis of the upper orbital wall as a bone reaction of different kinds of anemias. The caries and its complications, such as destruction of the dental crown to the radix, granulomatous lesions and cysts of the affected tooth adjoining tissues were frequent even in young individuals. According to Tcholakov (1993), the paradontopathy in adult and juvenile individuals confirmed that the alveolar osteolysis was not a senile atrophy but a result of pathological resorption. The author's conclusion was that the conditions of life for the medieval population of Drustur were not very favourable. These paleopathological findings are similar to ours.

\section{Conclusions}

The paleopathological findings among the investigated cranial series showed that the living conditions were not very favourable for the medieval population of Drustar.

Cases of amenia and the high frequency of dental caries with related complication in young and adult individuals are probable evidences for a bad nourishing diet. On the other hand, the two survived battle injuries are an indicator for the level of the medical practice.

Our results are similar and confirm the conclusions obtained by previous investigations of this region and period. 


\section{Acknowledgments}

This work was supported by the European Social Fund and Republic of Bulgaria, Operational Programme "Human Resources Development" 2007-2013 framework, Grant № BG051P0001-3.3.06-0048 from 04.10.2012.

\section{Reference}

Angelova, St. (2002). Razkopkite na tsarkva No 2. Arheologichesko prouchvane na Drustar /14 godini po-kasno/. Sbornik "Dobrudzha", 20, 12-39. lin Bulgarian/

Aufderheide, A.C. \& Rodriguez-Martin, C. (1998). The Cambridge Encyclopedia of Human Paleopathology. Cambridge: Cambridge University Press.

Boev, P., Kondova, N. \& Cholakov, Sl. (1981). Zabolyavaniya i travmi v srednovekovna Bulgaria. Dokladi, I Natsionalen kongres po istoriya na medicinata, Shumen, 38-48. /in Bulgarian/

Kondova, N., Boev, P. \& Tcholakov, Sl. (1982). Paleopathology of the medieval Bulgarian population. Man and his origins, Anthropos |Brnol, 21, 379-382.

Kondova, N. \& Cholakov, SI. (1992). Paleodemographic and paleopathologic data of late antique population of Augusta Trayana. Acta cytobiologica et morphologica, BAS, 2, 8-16.

MacLeod, S.P. \& MacIntyre, D.R. (1992). Case report: Calcification of genioglossus: a painful radiographic finding. Clin. Radiol., 46(2), 137-138.

Ortner, D. (2003). Identification of pathological conditions in human skeletal remains. San Diego: Academic Press.

Selvamuthukumar, S.C., Aswath, N. \& Karthika B. (2010). Case report: An incidental finding of enlarged genial tubercles in a case of oral carcinoma. Journal of Indian Academy of Oral Medicine and Radiology, 22(2), 99-101.

Tcholakov, SI. (1993). An anthropological study of a medieval cemetery at the city of Drustur. Annuaire de l'universite de Sofia "St. Kliment Ohridski", Faculte D' Histoire, 86, 105-133. 